\title{
Correlation Between A Self-Regulated Learning to Student Workers Academic Achievement
}

\author{
Yuzarion Zubir \\ STKIP PGRI Sumatera Barat, Indonesia \\ yuzarionzubir11@gmail.com
}

\author{
Desta Fandri \\ STKIP PGRI Sumatera Barat, Indonesia \\ desta.fandri@yahoo.com
}

\begin{abstract}
This research was based of antithesis assumption that self-regulated learning (SRL) has not correlation with student academic achievement who has been work. Design of this research was correlation analysis, to tested a correlation of variables. With 193 samples, that selected use purposive random sampling technique. Data were collected through SRL Scale and GPA of academic student (IPK). The SRL Scale has validity 0.431-1.00, construct validity 0.899 , and item validity 0.349-0.899 with Alpha Cronbach reliability 0.911. Result of this research concluded SRL has a positive correlation with student academic achievement who has been work. And may define that high SRL can determine the high of academic achievement.
\end{abstract}

Keywords: self-regulated learning, academic achievement

\section{INTRODUCTION}

University as high education organization in Indonesia, especially at west sumatera, in lastest years has admire from social worker, for continue to level of high education. Actually this is normal event that has been a requirement to have a better job and profession, so "you must be graduated from university". Because of that, student with the background from social worker family a properly, must be gain with education and many things to achieve more knowledge rather than regular students, although arranged of time between work and studies a crucial point.

The one of supported to gain good academic achievement for student from social worker is ability to self-regulation in learning, ability to arrange and selfdirection in learning. Ability to have a good selfregulate, arrange, and direction, will make their accopmplished a study in time at university. This ability in educational psychology known as selfregulated learning (SRL).

Zimmerman was known to make popular SRL. He has purpose that placing a student participation in activity such metacognitive, motivational, and behavioral in learning [6]. In a context of learning at university is placing an active participation from regular student and student of social worker. Active participation of student on metacognitive, motivational, and behavioral is the implication in this research. To be more specific which mean ability to self-regulation, self-arrangement and self-direct with actively such metacognitive, motivational and behavioral.

First, ability to regulate a metacognitive, selfregulation capability has not separated with ability of metacognitive. Because metacognitive will bridging learning behavior. That cause by individual knowledge about their own cognition will guide and reconstruct their learning behavior. A form of metacognitive regulation, shaping a student to have ability: (1) making college plan; (2) organizing college agendas; (3) to examined self-capability in college; and (4) to self-instruction in college process.

Second, regulation of motivation, this has a relation with ability to self-motivation from the inside, to achieve one purpose. To be a student workers, it's relation with finishing a study in time. Reconstructed of Zimmerman and Pons (1990), about regulated motivation is mean evolving a deep activity to starting, to cementing of will, arrange to make activity, and other energies to make a rise of spirit, preparing task, and finishing it as soon as possible that corresponding with purposive of learning [5].

Third, behavioral regulation, behavioral has a many things, start with attitude in learning and control of activity in learning such overt or covert behavior. Student workers activity that correlate with student ability: (1) regulate behavior in learning; and (2) make use of environment to support their activity, this is same line with reconstruction that purpose by Zimmerman (2004). Self-regulation capability and selfdirect on actively such metacognitive, motivational and behavior in academic activity that has been description above has an impact to student academic achievement [7].

Academic achievement is quantitative expertise that person earn from a learning process. Quantitative expertise such a number or score that gain by student from learning process. This grade or score was call with academic achievement. This line with Alsa (2005) quantitative score from examination call as learning achievement [1].

However, bad or high achievement was influence by SRL. Research that conduct by Yuzarion (2014) found that SRL has a significant positive correlation to student achievement at SMP N Kota Malang [4]. In line with description above, a phenomena founded that contrast with the reality of student workers in STKIP PGRI Sumatera Barat. That found a problem which link with SRL and academic achievement such: (1) Student workers has not make a plan of learning; (2) a Student Workers has not organizing; (3) has not measure self-capability in learning; (4) self-uninstructed in learning; (5) has a low on learning motivation; (6) has not self-regulated well; and (7) has not use a learning environment very well, (8) Academic achievement in a lower level. In that phenomena, writer and research team conduct such research with correlation self-regulated learning (SRL) with academic achievement of student workers in STKIP PGRI Sumatera Barat. 


\section{METHODS}

This research was ex post facto. Purpose to test a correlation between a variable to the others that has been done in natural setting ways. Research design a correlation logic. Research population all student workers that active in learning in STKIP PGRI Sumatera Barat, and 193 sample was collected through purposive random sampling.

Data was collected with SRL Scale, SRL was awareness efforts of student workers to regulated and direct their self in learning to make perceived of ability to do metacognition regulation, about college plan, organize, and measure their capability, self-instructed in learning. Regulation of motivation was link with make an impulse from the inside to achieve a higher academic achievement, and regulated behavior, make an useful a environment. Although academic achievement was a cumulative indexation (IPK). Hypothesis in this research was.

Ho : Self-regulated learning (SRL) has not correlation with student workers academic achievement in STKIP PGRI Sumatera Barat.
Ha : Self-regulated learning (SRL) has a correlation with student workers academic achievement in STKIP PGRI Sumatera Barat.

After finishing a SRL scale, next phase was to testament such field tested to 33 student and the result was content validity $0.431-1.00$, construct validity 0.899 , item validity $0.349-0.899$ and reliability grade with alpha cronbach 0.911 . so this worthy to be an instrument on the fileld.

\section{RESULT}

Tested hypothesis in this research with Pearson correlation. Equation using SPSS program 20 version for windows, equation result can be seen at Table 1 . According to that Table 1, can we explain that correlation coefficient and score in significant grade between SRL and cumulative indexation student workers. That analysis has known between variable research has gained coefficient correlation score 0.925 , that was close to a perfection. It can be conclude very positive correlation between SRL with cumulative indexation achievement of student workers STKIP PGRI Sumatera Barat.

Table I

Correlation between SRL and Cumulative Indexation on Student Workers

\begin{tabular}{llcc}
\hline \multicolumn{3}{c}{ Correlations } \\
\hline \multirow{3}{*}{ SRL } & SRL & IPK \\
& Pearson correlations & 1 & $925^{* *}$ \\
& Sig. (2-tailed) & & .000 \\
\multirow{3}{*}{ PPK } & N & 193 & 193 \\
& Pearson correlations & $925^{* *}$ & 1 \\
& Sig. (2-tailed) & .000 & \\
& N & 193 & 193 \\
\hline
\end{tabular}

While significant tested, in column two tailed (2-tailed) on that table, result of hypothesis shown; SRL has correlation with academic achievement student workers STKIP PGRI Sumatera Barat. On that table, can be found significant score $0.000<0.05$, that mean alternative hypothesis $\mathrm{H}_{\mathrm{o}}$ has been refuse. It can be concluded that SRL has a correlation with academic achievement of student workers STKIP PGRI Sumatera Barat, with a positive correlation. The increase of SRL will increase an Academic Achievement student, and cumulative indexation will increase to.

\section{DISCUSSION}

According to that found, SRL has correlation with academic achievement student workers STKIP PGRI Sumatera Barat, can be concluded SRL has a correlation with academic achievement with score correlation 0.925 , a positive correlation, its mean increasing of SRL will increase student academic achievement. If student SRL was good, that will effect to their academic achievement. And also contrary if SRL has bad and it will decrease student academic achievement. SRL as a one of form of capability to regulation and directed of self in learning, in this context was learning in college level. College student was educated with adult education, so self-regulated cannot be separated in the process of student learning. It has been prove with research founded.
The implication, of this research was active participation from student in learning such metacognitive, motivational and behavioral in learning that was a capability of self-regulation, self-organizing, and self-directed with actively to support a student such motivational, metacognitive and behavioral. Selfregulated capability cannot separated with metacognition capability. Because very important things of metacognitive bridging a learning behavior, which consist of regulated, organize, directed self. That because of their own experience, knowledge and cognition has guide them in learning, how to manage and accomplished their task.

The realization was a student can make a plan of study, organize their college agendas, to measure their ability in learning, and to instruction their self to move forward in learning. And of course same thing with regulation of motivating, this is line with ability to invoke self-impulse, to achieve one purpose to graduate in time. To regulate a behavior, this activities has a strong correlation with student capability to organize their behavior in learning and make a useful the environment that can be supporting their activities. It is line with reconstruction of SRL that conduct by Zimmerman (2004). Academic achievement is quantitative expertise that person earn from a learning process. Quantitative expertise such a number or score that gain by student from learning process. This grade or score was call with academic achievement. 


\section{CONCLUSION}

According previous analysis of this research above, it can be concluded, SRL has a positive correlation to student workers academic achievement, with correlation coefficient 0.925 , it mean increasing SRL will increase student academic achievement too.

According to conclusion, researcher has a recommendation, student has a work in their learning process at college to make an optimization of three basic capability of SRL such metacognitive, regulation of motivation, and capability to regulated learning behavior.

\section{REFERENCES}

[1] Alsa, A. 2005. Program Belajar, Jenis Kelamin, Belajar Berdasar Regulasi Diri dan Prestasi Belajar Matematika Pada Pelajar SMA Negeri di Yogyakarta. Dissertation. Yogyakarta: University of Gadjah Mada.

[2] Bandura, A. 1986. Social Fundations of Thought and Action: A Social Cognitive Theory. New Jersey: Prentice-Hall, Inc.

[3] Hair, J. F. J., Black, W. C., Babin, B. J., Anderson, R. E., \& Tatham, R. L. 2010. Multivariate Data Analysis. New Jersey: Prentice Hall.

[4] Yuzarion. 2015. Studi Teoritis Faktor yang Mempengaruhi Prestasi Belajar Peserta Didik. Jurnal Ilmu Pendidikan, 42(2), 182-191.

[5] Zimmerman, B. J. 1989. A Social Cognitive View of Self-Regulated Academic Learning. Journal of Educational Psychology, 81(3), 329-339.

[6] Zimmerman, B. J. 2004. Sociocultural in Fluence And Students' Development Of Academic Self-Regulation: A Social-Cognitive Perspective. In McInerney, D. M., \& VanEtten, S., (Eds.)., Big Theories Revisted. Greenwhich: Information Age.

[7] Zimmerman, B. J., \& Martinez-Pons, M. 1990. Student Differences in Self-Regulated Learning: Relating Grade, Sex, and Giftedness to Self-Efficacy and Strategy Use. Journal of Educational Psychology, 82(1), 51-59.

[8] Zumbrunn, S., Tadlock, J., \& Roberts, E. D. 2011. Encouraging Self-Regulated Learning in the Classroom. A Review of the Literature, 22(1), Retrieved July $\quad 1, \quad 2017, \quad$ from http://www.selfregulation.ca/download/pdf_documents/ Self $\% 20$ Regulated\%20Learning.pdf. 